\title{
Genetic counseling throughout the life cycle
}

\author{
Leslie J. Ciarleglio, ${ }^{1}$ Robin L. Bennett, ${ }^{2}$ Jennifer Williamson, ${ }^{3}$ \\ Jessica B. Mandell, ${ }^{4}$ and Joan H. Marks ${ }^{5}$ \\ ${ }^{1}$ Yale University School of Medicine, New Haven, Connecticut, USA \\ ${ }^{2}$ Medical Genetics Clinic, University of Washington, Seattle, Washington, USA \\ ${ }^{3}$ Gertrude H. Sergievsky Center, Columbia University College of Physicians and Surgeons, \\ New York, New York, USA \\ ${ }^{4}$ King Laboratory, Departments of Medicine and Genome Sciences, \\ University of Washington, Seattle, Washington, USA \\ ${ }^{5}$ Human Genetics Program, Sarah Lawrence College, Bronxville, New York, USA
}

\begin{abstract}
As the definition of genetic counseling continues to evolve (see the related article beginning on page 1274), so does the application of genetic counseling services in all areas of medicine and throughout the human life cycle. While governmental policy, economics, ethics, and religion continue to influence society's views regarding the necessity of testing germ cells for mutations to prevent the birth of an affected child or predicting whether healthy adults will develop future life-threatening illness, patient autonomy in the choice of whether to know, or not know, one's genetic make-up remains a core principle of genetic counseling.
\end{abstract}

J. Clin. Invest. 112:1280-1286 (2003). doi:10.1172/JCI200320170.

Genetic counseling is an expanding field in the era of genomic medicine. This unique medical specialty provides clinical health care, education, and emotional support to individuals and families facing genetic and inherited diseases. Genetic counselors provide services to patients across the lifespan by assessing family and environmental history to determine disease risk; assisting in genetic testing, diagnosis, and disease prevention and management; and offering psychosocial and ethical guidance to help patients make informed, autonomous health care and reproductive decisions (Figure 1 ). The purpose of this article is to provide an

Address correspondence to: Robin L. Bennett, University of Washington, Medical Genetics, Box 357720, Seattle, Washington 98195-7720, USA. Phone: (206) 616-2135; Fax: (206) 616-2414;

E-mail: robinb@u.washington.edu.

Conflict of interest: The authors have declared that no conflict of interest exists.

Nonstandard abbreviations used: congenital heart disease (CHD); Risk Evaluation and Education for Alzheimer's Disease (REVEAL). authoritative review of genetic counseling, its role in the front lines of genetic health, and its impact on medical research, education, and patient care.

\section{Prenatal diagnosis: congenital heart disease}

There was a time when prenatal genetic counseling was reserved for highrisk patients. For many years, the term "high-risk" was generally defined by a maternal age of 35 years or older at the time of expected delivery. That definition has evolved significantly as an increasing number of tests have become available to pregnant patients and the list of conditions amenable to prenatal diagnosis has grown. Now, all pregnant women and women planning pregnancy are potential candidates for genetic counseling. Yet the array of testing options can be mindboggling for patients and their health care providers, and the associated anxiety may be magnified logarithmically when test results are abnormal. The genetic counselor plays a crucial role in deciphering this information for families, while simultaneously providing emotional support.

Heart defects are among the most common birth defects and are the leading cause of death in the first year of life $(1,2)$. Congenital heart disease (CHD) occurs with a frequency of about 8 per 1,000 births. Approximately $25 \%$ of all infant deaths are due to congenital malformations, $30 \%$ of which are related to CHD (3). There is an increased incidence of CHD in stillborns (4), and autopsy studies suggest that the incidence of fetal CHD may approach 30 per 1,000 (5). Because the majority of infants with CHD are born to mothers with no well-defined risk factors, an increasing number of affected fetuses are identified during routine obstetric scanning (5-8). Consequently, genetic counseling for patients facing the prenatal identification of CHD is common.

Although the majority of CHD cases are sporadic in nature, the current understanding of the major steps of cardiac development allows for categorization of defects by common embryonic origin. The cardiovascular system is the first major system to function during fetal development. The primitive heart, derived from embryonic mesoderm and neural crest cells, begins to form around embryonic day 18 and beats by day 22. The early heart begins as the endocardial tube, which bends, loops, and ultimately partitions itself into the four well-recognized chambers, establishing the basis for separation of pulmonary and systemic blood flow at birth (9). In the case of CHD that is not clearly related to known risk factors (see below), insight has been gained into the underlying genetic mechanisms of abnormal heart formation through an understanding of the embryologic development of the heart (10-13).

Risk factors related to CHD are well described. Maternal risk factors include diabetes, phenylketonuria $(14,15)$, viral infection such as rubella, and specific exposure to agents such as alcohol, 
antiseizure medications, Accutane, and lithium. Fetal risk factors include suspected heart disease by routine ultrasound, a known fetal chromosome abnormality, extracardiac structural anomalies, fetal hydrops, and fetal arrhythmia $(6,7,16)$. The presence of any risk factor significantly increases the likelihood of developing fetal heart disease, and genetic counseling and fetal echocardiography are clearly indicated in these cases.

\section{Prenatal genetic counseling}

For pregnancy-related issues, there are two general types of genetic counseling sessions - those where parents or prospective parents are concerned about potential risks and outcomes of pregnancy, and those where patients are dealing with a specific fetal diagnosis during pregnancy (17). Despite the vastly different nature of these sessions, their courses are similar. All clients come to genetic counseling with some level of anxiety, even in the most routine of circumstances. Fear of the investigation of one's own basic genetic make-up is common, particularly in the prenatal setting. The risk of a problem, or the diagnosis of a specific anomaly during pregnancy, is often a prospective parent's biggest fear. This anxiety can be overwhelming and may significantly impact a patient's selfimage. Such issues need to be explored, acknowledged, and accounted for throughout the counseling session.

Prior to the initial counseling appointment for an already identified fetal anomaly like heart disease, the counselor will ideally have had the opportunity to contact the family to prepare them for the discussion and to begin to develop a rapport. At the initial visit, parents are often asked to recount how the diagnosis was made and what information they have obtained thus far. This allows the family members to "tell their story" in their own words. Such recounting of family history helps the counselor assess their understanding of the diagnosis, their informational resources, and their coping strategies. It also fosters trust between the counselor and the clients.

Immediately after the diagnosis of a fetal cardiac anomaly, most families are not in the frame of mind to construct a detailed three-generation pedigree. The counselor obtains an abbreviated version by asking about family and obstetrical history, use of medications, and illnesses or other exposures in pregnancy (18). The specific fetal cardiac diagnosis, including implications, severity, and natural history, is discussed in detail, as well as options for further testing and for prenatal management. All of these are influenced by gestational age at the time of the diagnosis (Table 1).

After considering the available options, the counselor and the clients determine a management plan. In addition to providing appropriate medical and emotional support, a management plan gives families some sense of control where many feel like victims in a situation beyond their control (13). Further testing, consultations with pediatric cardiologists, nurses, and surgeons, and tours of delivery suites and special-care nurseries may be planned $(5,6)$. Additionally, lay literature and guidance about appropriate Internet sites and other resources are critical for families and reinforce issues covered in the session (19).

\section{Treating CHD}

No specific treatment is currently available to improve the course of structural heart disease in utero. However, prenatal diagnosis of a fetal cardiac defect provides the opportunity for counseling, education, and discussion of perinatal options. Although several studies have shown no significant difference between prenatal and postnatal diagnosis in terms of the subsequent costs of initial hospitalization, length of hospital stay, and neonatal survival $(3,20)$, early detection is helpful in allowing the family to meet the health care team and to discuss the diagnosis in a non-crisis situation. More importantly, parents may prepare emotionally for the birth of a child with CHD, rendering them better able to make informed decisions about medical and surgical options following delivery. Ideally, CHD-related morbidity will decrease and the clinical outcome will improve for the affected child if treatment is started before the infant develops severe symptoms (5, 21). One study demonstrated fewer seizures in neonates with hypoplastic left heart syndrome diagnosed prenatally, compared with those diagnosed at birth (22), suggesting that prenatal diagnosis might improve long-term neurologic outcome.

\section{Exploring postdiagnosis options}

The option of pregnancy termination is necessarily integrated into the counseling of families with fetal anomalies. The hope of surgical correction or palliation for CHD makes this discussion particularly difficult. Parents need to be fully aware of detailed information regarding the risks, benefits, and time constraints of the different methods of termination. Counselors are often asked, "What would you do in this situation?" It is unfair to the patient to answer that question directly, as there is such great variation in individuals' perspectives, needs, and goals. The genetic counselor may instead review issues that would help patients to reach their own decisions. Another difficult issue is cost. Many families have financial concerns about medical bills for a child that may require multiple major surgeries. They also fear the emotional cost to siblings of the affected child. These complex aspects of prenatal genetic counseling may be discussed over several sessions.

As current medical technology affords detailed evaluation of the developing fetus, and as the underlying genetic mechanisms of fetal maldevelopment are better understood, the lines defining high and low risk, and normal and abnormal, will continue to blur. Genetic counselors are uniquely trained to help patients deal effectively with the heavy emotional burdens and subsequent choices imposed by the availability of this information.

\section{Pediatric genetic disease and newborn screening}

Pediatricians and other health professionals who work with children with birth defects and genetic disorders with dysmorphic features have long been referring parents for genetic counseling. These families are usually most concerned about natural history, prognosis, consumer networks, and resources related to their child's condition. Eventually the family's thoughts turn to risks for future pregnancies. 
Table 1

Options for prenatal testing

\begin{tabular}{|c|c|c|c|c|c|}
\hline $\begin{array}{l}\text { Gestational age } \\
\text { (weeks) }\end{array}$ & Test & Description & Screening vs. diagnostic & Information obtained & $\begin{array}{l}\text { Risks to } \\
\text { pregnancy }\end{array}$ \\
\hline Pre-conception & $\begin{array}{l}\text { Parental-carrier } \\
\text { testing }\end{array}$ & $\begin{array}{l}\text { A variety of tests for } \\
\text { genetic diseases more common } \\
\text { in specific ethnic groups. } \\
\text { Includes cystic fibrosis, fragile } \\
X \text { syndrome, Jewish panel, } \\
\text { sickle cell anemia, multiple } \\
\text { thalassemias }\end{array}$ & $\begin{array}{l}\text { Diagnostic if test } \\
\text { is positive. A negative } \\
\text { test does not exclude } \\
\text { the possibility that the } \\
\text { individual is a gene } \\
\text { carrier }\end{array}$ & $\begin{array}{l}\text { Identifies all or most } \\
\text { gene carriers. Allows } \\
\text { planning if further testing } \\
\text { indicated or to plan for } \\
\text { prenatal diagnostic testing }\end{array}$ & None \\
\hline $8-14$ & $\begin{array}{l}\text { First-trimester } \\
\text { ultrasound }\end{array}$ & $\begin{array}{l}\text { Often accomplished vaginally. } \\
\text { Increasingly used in pregnancy } \\
\text { evaluation and management. } \\
\text { Often involves nuchal } \\
\text { translucency measurement }\end{array}$ & $\begin{array}{l}\text { Screening and/or } \\
\text { diagnostic }\end{array}$ & $\begin{array}{l}\text { Fetal viability, pregnancy } \\
\text { dating, limited evaluation } \\
\text { of fetal anatomy. Increased } \\
\text { nuchal translucency } \\
\text { measurement is associated } \\
\text { with increased risk of } \\
\text { aneuploidy and CHD }\end{array}$ & None \\
\hline $10-14$ & $\begin{array}{l}\text { First-trimester } \\
\text { fetal echo- } \\
\text { cardiography }\end{array}$ & $\begin{array}{l}\text { Emerging technology that } \\
\text { attempts to visualize cardiac } \\
\text { view routinely obtained in the } \\
\text { second-trimester fetal } \\
\text { echocardiogram, at earlier gestational } \\
\text { ages. Often accomplished by vaginal } \\
\text { ultrasound }\end{array}$ & Screening & $\begin{array}{l}\text { Four-chamber view of } \\
\text { the fetal heart. Adequate } \\
\text { views of outflow tracts } \\
\text { are less likely to be obtained } \\
\text { at these earlier gestational } \\
\text { ages }\end{array}$ & None \\
\hline $11-14$ & $\begin{array}{l}\text { First-trimester } \\
\text { screening }\end{array}$ & $\begin{array}{l}\text { Based on three parameters: } \\
\text { (a) maternal age; (b) fetal nuchal } \\
\text { translucency, measured by a } \\
\text { specially trained and certified } \\
\text { sonographer; and (c) biochemical } \\
\text { analysis of maternal serum }\end{array}$ & Screening & $\begin{array}{l}\text { Estimated risk of fetal } \\
\text { Down syndrome and } \\
\text { trisomy } 18\end{array}$ & None \\
\hline $11-14$ & $\begin{array}{l}\text { Chorionic villus } \\
\text { sampling }\end{array}$ & $\begin{array}{l}\text { Biopsy of developing placenta. } \\
\text { Available to all pregnant women; } \\
\text { routinely offered to women of } \\
\text { ages } 35 \text { and over at time of } \\
\text { delivery, and women determined } \\
\text { to be at sufficient risk based } \\
\text { on other screening tests }\end{array}$ & Diagnostic & $\begin{array}{l}\text { Fetal karyotype, } \\
\text { DNA diagnostics }\end{array}$ & $\begin{array}{l}\sim 1 \% \text { risk } \\
\text { of pregnancy } \\
\text { loss }\end{array}$ \\
\hline $15-22$ & $\begin{array}{l}\text { Maternal-serum } \\
\text { screening }\end{array}$ & $\begin{array}{l}\text { Blood test offered to all } \\
\text { pregnant women to assess } \\
\text { risk of certain birth defects }\end{array}$ & Screening & $\begin{array}{l}\text { Estimated risk of fetal } \\
\text { Down syndrome, trisomy } \\
18, \text { and open neural tube } \\
\text { defects }\end{array}$ & None \\
\hline $16-24$ & $\begin{array}{l}\text { Targeted fetal } \\
\text { ultrasound }\end{array}$ & $\begin{array}{l}\text { Available to all pregnant women. } \\
\text { A commonly relied upon tool } \\
\text { in pregnancy evaluation and } \\
\text { management }\end{array}$ & $\begin{array}{l}\text { Screening and } \\
\text { diagnostic }\end{array}$ & $\begin{array}{l}\text { Fetal anatomy, fetal biometry } \\
\text { and growth, assessment of } \\
\text { placenta and amniotic fluid } \\
\text { volume }\end{array}$ & None \\
\hline $15-22$ & $\begin{array}{l}\text { Genetic } \\
\text { amniocentesis }\end{array}$ & $\begin{array}{l}\text { Process of obtaining an amniotic } \\
\text { fluid sample. Available to all } \\
\text { pregnant women; routinely offered } \\
\text { to women of ages } 35 \text { and over at } \\
\text { delivery, and women determined } \\
\text { to be at sufficient risk based on } \\
\text { other screening tests }\end{array}$ & Diagnostic & $\begin{array}{l}\text { Fetal karyotyping, DNA } \\
\text { diagnostics, biochemical } \\
\text { analysis of amniotic fluid }\end{array}$ & $\begin{array}{l}\sim 0.5 \% \text { risk } \\
\text { of pregnancy } \\
\text { loss }\end{array}$ \\
\hline $18-24^{\mathrm{A}}$ & $\begin{array}{l}\text { Fetal echo- } \\
\text { cardiography }\end{array}$ & $\begin{array}{l}\text { Ultrasound of the fetal heart, } \\
\text { performed by practitioners } \\
\text { experienced with fetal heart anatomy. } \\
\text { Recommended for pregnant patients } \\
\text { with known maternal or fetal } \\
\text { risk factors }\end{array}$ & Diagnostic & $\begin{array}{l}\text { Detailed views of fetal } \\
\text { cardiac structure, rhythm, } \\
\text { and blood flow }\end{array}$ & None \\
\hline$\geq 18$ & $\begin{array}{l}\text { Fetal blood } \\
\text { sampling }\end{array}$ & $\begin{array}{l}\text { Typically reserved for specific } \\
\text { high-risk situations }\end{array}$ & Diagnostic & $\begin{array}{l}\text { Fetal karyotyping, DNA } \\
\text { diagnostics, fetal blood } \\
\text { parameters }\end{array}$ & $\begin{array}{l}1-5 \% \text { risk } \\
\text { of pregnancy } \\
\text { loss }\end{array}$ \\
\hline
\end{tabular}

AThis test is increasingly being used in the late first and early second trimesters.

Some pediatric genetic conditions have clinical features that, however, are not so apparent. More and more children whose genetic disorders would otherwise go undetected are diagnosed through newborn screening. If diag- nosed early enough in life, many diseases can be treated or prevented. Genetic counseling for affected children and families is integral in medical management, family planning, and emotional coping.

\section{The challenges of screening and counseling}

The palette of diseases that should be screened in newborns is murky with the advent of new technologies such as tandem mass spectrometry, which allows 
simultaneous testing for multiple genetic diseases (23). With hundreds of diseases affecting newborns, how can parents and health professionals decide which genetic disorders should be included in a screen? Traditionally, policy regarding newborn screening has been defined by basic principles (see Principles of newborn screening for the detection of genetic diseases), although decisions on which disorders to screen for are regulated by individual states. In March 2003, the US General Accounting Office, the body responsible for the audit, evaluation, and investigation of congressional policy and funding decisions, provided a report to congressional requesters, reviewing the variation among state newborn-screening programs and including information on the criteria considered in selecting disorders to include in state programs (see Principles of newborn screening for the detection of genetic diseases; and the National Newborn Screening and Genetics Resource Center website at http://genes-r-us.uthscsa.edu) (24).

Determining which disorders should be included in newborn screening entails considerable difficulty, as is apparent from the variety of diseases screened by different states. Currently, the number of diseases screened ranges from four to 36 , with the majority being eight or fewer (24). The disorders most commonly screened include phenylketonuria, congenital hypothyroidism, galactosemia, sickle cell disease, and congenital adrenal hyperplasia.

Some policy makers maintain that newborn screening for untreatable genetic disorders is reasonable only for the purpose of preventing the birth of another affected child. When a child has a genetic disorder identified by newborn screening, genetic counseling is paramount for a woman and her partner in order to address the complicated reproductive decisions that may follow. For example, a boy with Duchenne muscular dystrophy (DMD) may go undiagnosed until he is four years old. As this is an X-linked disease transmitted by the mother, the boy's mother may already have at least one other at-risk son. If the diagnosis of DMD had been made with her first newborn, she might have had the opportunity, through genetic counseling, to plan for future pregnancies using prenatal diagnosis, permanent forms of birth control, preimplantation diagnosis, or even ovum donation.

Another issue in newborn screening is that limited data exist to determine when interventions should begin in newborns identified with genetic disease. Interventions may be quite expensive, with enzyme-replacement therapy for lysosomal-storage disorders such as Fabry disease and Gaucher disease costing between $\$ 70,000$ and $\$ 200,000$ per year in affected adults (25). Evidence suggests that the effects of storage disorders are manifest in childhood (26, 27). Yet the question remains: is this reason enough to provide newborn screening so that treatment may begin at birth? Is it acceptable to test healthy minors even if no therapy or intervention is available or if best age at intervention, e.g., enzyme replacement theory, is unknown (27-30)? Natural history registries of genetic diseases could provide some of this helpful information, but few exist. Genetic counselors serve critical functions in developing and implementing such registries, to elucidate the implications of genetic diseases throughout the lifespan. Most natural history registries are funded through grants to individual researchers or research consortiums working with patient advocacy groups or with pharmaceutical companies (31-33).

\section{Genetic predisposition \\ to adult-onset disease}

The identification of susceptibility genes for common adult-onset genetic diseases is moving the field of genetic counseling in a new and challenging direction. Common diseases such as diabetes, certain cancers, and adultonset neurodegenerative diseases have an identified genetic component or have been linked to specific chromosomal regions through family linkage and association studies (Table 2). Genetic counseling for these diseases is difficult when the disease is linked to susceptibility genes, which are known to confer an increased risk of disease, rather than deterministic genes, which are predictive of disease onset. With the identification of genes associated with Alzheimer disease, there is considerable interest in the clinical application of this genetic information through genetic counseling and testing.

\section{Alzheimer disease}

Alzheimer disease is characterized by gradual onset and progressive cognitive decline, with motor and sensory dysfunction occurring in the later stages (34). Common symptoms include

\section{Principles of newborn screening for the detection of genetic diseases}

The disorder should be common.

The disease should manifest in childhood with severe complications, e.g., high burden.

An accurate diagnostic test should exist with a minimal percentage of false positives and/or false negatives. It is considered more acceptable to identify a false positive than to miss an affected child.

The mode of sampling and screening should not be harmful, e.g., a heel stick for obtaining blood.

Timely results should be available. Some states do not offer newborn screening for galactosemia because hospital staff often diagnose symptomatic infants in the first days of life before newborn-screening results are available.

An immediate intervention that significantly changes the natural history of the disease should be available if the diagnosis is made soon enough after birth. For example, implementation of a phenylalanine-restricted diet significantly alters the natural history of phenylketonuria. This service is often provided by specialized metabolic centers with access to geneticists, genetic counselors, nutritionists, and social workers.

Screening should be cost-effective, which may be difficult to determine.

The screening program should have a comprehensive system in place to provide education to parents and health care providers. 


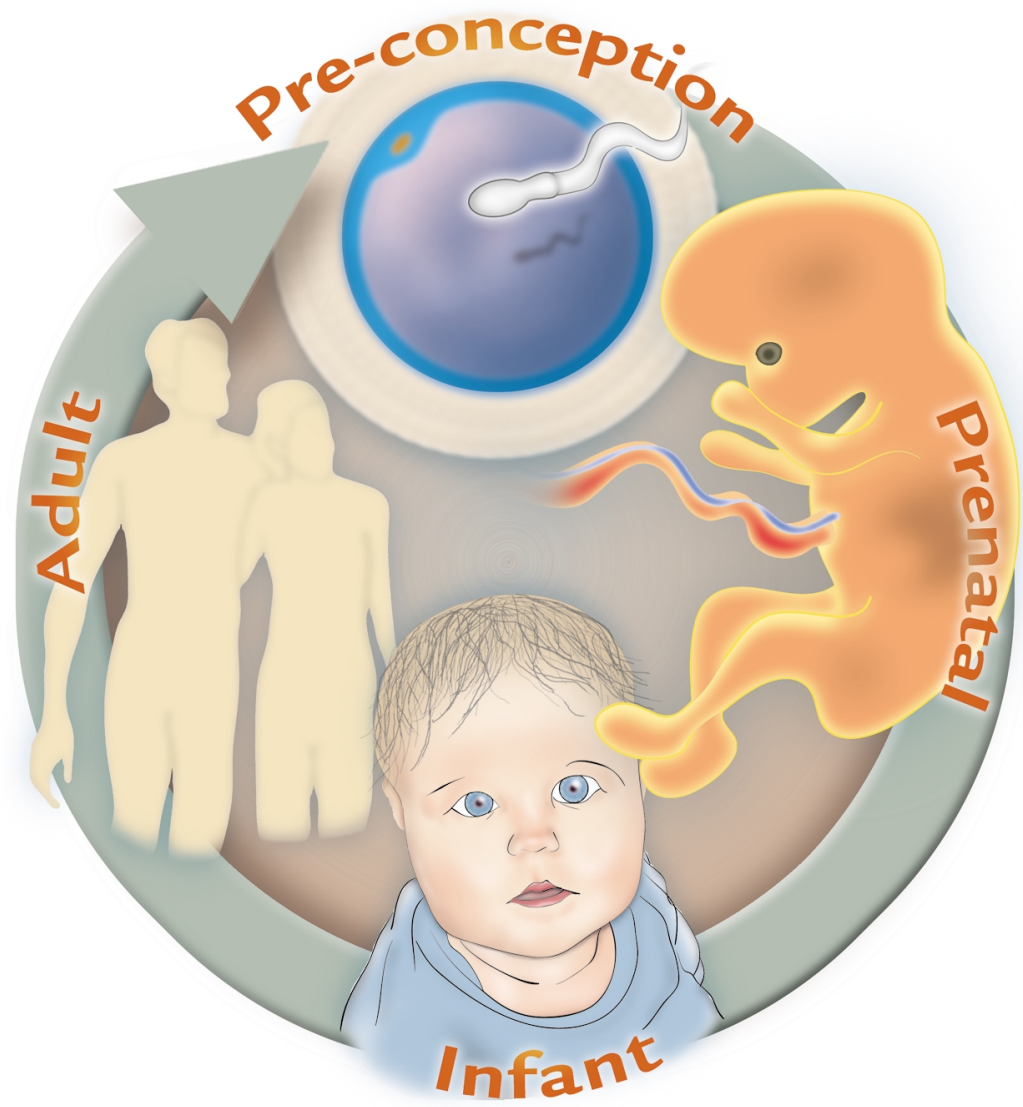

Figure 1

Genetic counseling is a unique medical specialty that provides clinical health care for patients across the lifespan facing genetic and inherited diseases.

memory loss, disorientation, confusion, language disturbance, and behavioral changes such as agitation, wandering, psychosis (hallucinations, delusions), depression, anxiety, and sleep disturbance (34). Alzheimer disease can be divided into early-onset sporadic and early-onset familial disease, occurring before 65 years of age, and late-onset sporadic and late-onset familial disease, occurring after 65 years of age. The majority of Alzheimer disease cases are associated with late-onset clinical presentation, while early-onset familial Alzheimer disease accounts for less than $5 \%$ of all cases (35).

Genetic studies have revealed several genes linked to Alzheimer disease. Three determinative genes, PSEN1 and PSEN2, encoding presenilin-1 and -2, respectively, and $A P P$, encoding amyloid- $\beta$ precursor protein, are associated with autosomal dominant early-onset Alzheimer disease, and one susceptibility gene, $A P O E$, encoding apolipoprotein $\mathrm{E}$, is associated with increased risk impact of risk assessment and genetic testing for late-onset Alzheimer disease by providing $A P O E$ genotyping and results (38). The National Institute on Aging has also established the Alzheimer's Disease Genetics Initiative: The Multiplex Family Study, creating federally funded Alzheimer disease centers throughout the US to facilitate collaboration between researchers conducting family-based linkage studies (www.alzheimers.org). This collaboration should identify more Alzheimer disease risk-factor genes.

\section{To test or not to test}

Risk evaluation for Alzheimer disease is challenging. Evaluation of an individual's risk depends on the family history of disease and whether it is early- or late-onset and familial or sporadic. In an early-onset family, a known mutation in an affected patient puts the siblings and children at a $50 \%$ risk of inheriting the same mutation. For a person with a family history of lateonset disease, risk is based on information gathered through family-based studies, and epidemiological research has shown that first-degree relatives' risk is two- to threefold greater than the background population's $10-15 \%$ risk of developing the disease (39). Many individuals seeking genetic counseling and testing for late-onset Alzheimer disease assume that genetic-test results are absolute or predictive of disease onset. While the presence of the APOE4 allele may confer greater risk for disease, this information is not conclusive. Until more useful risk figures using the APOE genotype are established, knowing the family history may be more informative than knowing the $A P O E$ genotype in risk assessment. Ultimately, genetic counseling facilitates an understanding of the importance of family history, other susceptibility factors such as the presence of $A P O E$, and the limitations of risk assessment.

For individuals diagnosed with Alzheimer disease, genetic counseling may involve family members in the decision of whether or not to pursue genetic testing or participate in genetic research studies. In such cases, the patient's capacity to consent to genetic testing may be in question. However, the family member serving as 
Table 2

Examples of adult-onset diseases and associated genes

\begin{tabular}{|c|c|c|c|c|}
\hline Disease & Known genes; proteins & Chromosome & Other possible loci & Reference \\
\hline \multirow[t]{4}{*}{ Alzheimer disease } & PSEN1; Presenilin-1 & 14 & $\begin{array}{l}\text { 9pter-p32.2, 12p, 12, 17q23, 3q26.1-q26.2, } \\
14 q 32.1,10 q 23-q 25,3 q 21,11 p 15.5 \\
17 q 11.1-q 11.2,19 q 13.1-q 13.3,19 q 32.2 m, \\
7 q 35,20 p 11.2,14 q 24\end{array}$ & 36,43 \\
\hline & PSEN2; Presenilin-2 & 1 & & \\
\hline & $A P P ;$ Amyloid- $\beta$ precursor protein & 21 & & \\
\hline & $A P O E ;$ Apolipoprotein $\mathrm{E}$ & 19 & & \\
\hline \multirow[t]{4}{*}{ Parkinson disease } & SNCA; $\alpha$-Synuclein & 4 & $1 p 35,2 p 13,4 p 15,12 p 11.2-q 13.1$ & 44 \\
\hline & DJ1; Oncogene DJ1 & 1 & & \\
\hline & UCHL1; Ubiquitin C-terminal esterase L1 & 4 & & \\
\hline & PARK2; Parkin & 6 & & \\
\hline \multirow[t]{9}{*}{$\begin{array}{l}\text { Diabetes mellitus, } \\
\text { type } 2\end{array}$} & NEUROD1; Neurogenic differentiation 1 & 2 & $\begin{array}{l}1 q 21-q 24,2 q, 3 q 27-q \text { ter, } 4 p \\
5 q 34-q 35.2,12 q, 20 q 12-q 13.1\end{array}$ & 45 \\
\hline & $H N F 4 A ;$ Hepatocyte nuclear factor $4 \alpha$ & 20 & & \\
\hline & TCF1; Transcription factor 1 & 12 & & \\
\hline & TCF2; Transcription factor 2 & 17 & & \\
\hline & SLC2A4; Solute carrier family 2 , member 4 & 17 & & \\
\hline & SLC2A2; Solute carrier family 2 , member 2 & 3 & & \\
\hline & GPD2; Mitochondria GAPDH 2 & 2 & & \\
\hline & MAPK8IP1; MAPK 8-interacting protein 1 & 11 & & \\
\hline & IRS $1 ;$ Insulin receptor substrate 1 & 2 & & \\
\hline \multirow[t]{7}{*}{ Breast cancer } & $B R C A 1$; Breast cancer 1 & 17 & $13 q 21,11 q, 11 p 15.5,17 q 22,8 q 11,20 q$ & 45 \\
\hline & $B R C A 2 ;$ Breast cancer 2 & 13 & & \\
\hline & TP53; Tumor protein p53 & 17 & & \\
\hline & $A R$; Dihydrotestosterone receptor & $x$ & & \\
\hline & PTEN; Phosphatase and tensin homolog & 10 & & \\
\hline & STK11; Serine/threonine protein kinase 11 & 19 & & \\
\hline & ATM; Ataxia telangiectasia mutated & 11 & & \\
\hline
\end{tabular}

health care proxy or legal guardian may be an at-risk daughter, son, or sibling with conflicting motivations for testing. Genetic counselors are instrumental in working with multiple family members to help them formulate a decision that serves the family unit and not just the at-risk individual or the patient with Alzheimer disease.

With any presymptomatic genetic test, genetic counseling also includes a discussion of the risks and benefits of testing. In the case of Alzheimer disease, risks include the psychological impact of finding that one carries an associated genetic factor for the disease, and the possibility of misunderstanding the risk associated with the APOE4 allele. Insurance costs and employment discrimination are additional concerns for many presymptomatic individuals. While there seems to be some debate as to whether genetic discrimination really occurs, genetic counseling addresses the possibility (40). Current state and federal legislation may not adequately protect people with a genetic susceptibility from high premiums or rejection from long-term care insurance and life insurance. While the Health Insurance Portability and Accountability Act (HIPAA) prohibits group health insurers from excluding presymptomatic individuals from coverage based on genetic-test results, this legislation does not apply to long-term care insurance or life insurance (41). Over 40 states have enacted laws regarding genetic discrimination, which may provide protection equal to or greater than that offered by HIPAA (www.nhgri.nih.gov/ Policy_and_public_affairs/Legislation/insure.htm). In the workplace, there is concern that genetic information could be used in hiring, firing, and promotion decisions. The Americans with Disabilities Act prohibits employers from discriminating against individuals with disabilities, but it is unclear how this law applies to those genetically predisposed to illness (42). Existing state laws address genetic discrimination and employment, and several federal genetic nondiscrimination bills addressing both insurance and employment are pending in the cur- rent congress (www.nhgri.nih.gov/ Policy_and_public_affairs/Legislation/workplace.htm and http://www. genome.gov).

\section{Benefits of predisposition genetic testing}

A primary motivation for a person to seek predictive testing is the ability to plan for the future. Individuals at risk for adult-onset diseases often have been shaped by the challenge of serving as caregiver for an affected parent or other family member. In the Alzheimer disease genetic counseling session, individuals discuss the emotional, physical, and financial difficulties of providing care for a loved one who cannot make decisions, complete day-to-day activities such as cooking, dressing, and paying bills, or enjoy activities such as family events or hobbies. Motivation for testing often stems from a desire to prevent passing the burden of this caregiving to the atrisk individual's children. Current information from the Alzheimer's Association (www.alz.org) on long- 
term care for dementia patients states that the average cost of nursing home care is $\$ 42,000$ per year and the average lifetime cost per patient is $\$ 174,000$. Individuals seeking genetic counseling hope that genetic testing can assist in planning future care.

At-risk individuals also seek information that may help them prevent the onset of disease. Prevention studies, however, are in clinical trials, and there are no current medical recommendations. Other topics discussed during genetic counseling include the possibility of participating in research studies like REVEAL and the Alzheimer's Disease Genetics Initiative. Participation in genetic research may be an alternative for individuals with a family history who do not want to pursue genetic testing or for whom genetic testing is not yet available, but who want to contribute to the understanding of the disease.

While the availability of genetic tests for Alzheimer disease is limited, the future may bring testing that targets specific populations for prevention and treatment. The ultimate goal of genetic research is the identification of at-risk individuals in order to facilitate early and effective treatments in the symptomatic person based on an individual's genotype and strategies to delay the onset of disease in the presymptomatic person. Such advances will enhance the practice of genetic counseling not only for Alzheimer disease but also for other complex adult-onset genetic diseases.

Genetic counselors fill a distinctive position in the complicated and varied arena of genomic medicine and health. Advances in genetic medicine create an even greater demand for expert health care services. Genetic counselors help meet this need, serving in almost every major medical center and across the globe as an increasingly important resource for medical referral and quality patient care. For an international list of genetic counselors and further information about genetic counseling, visit the website of the National Society of Genetic Counselors (www.nsgc.org).

1. MOD Birth Defects Foundation. 1999. Congenital heart defects. Fact Sheet.

2. Haak, M.C., and van Vugt, J.M.G. 2003. Echocardiography in early pregnancy: review of the litera- ture. J. Ultrasound Med. 22:271-280.

3. Jaeggi, E.T., Sholler, G.F., Jones, O.D.H., and Coop er, S.G. 2001. Comparative analysis of pattern, management and outcome of pre- versus postnatally diagnosed major congenital heart disease: a population-based study. Ultrasound Obstet. Gynecol. 17:380-385

4. Hoffman, J.I.E. 1995. Incidence of congenital heart disease. II. Prenatal incidence. Pediatr. Cardiol. 16:155-165

5. Brumund, M.R., and Lutin, W.A. 1998. Advances in antenatal diagnosis and management of the fetus with a heart problem. Pediatr. Ann. 27:486-490.

6. Kleinman, C.S., and Copel,J.A. 1994. Prenatal diagnosis of structural heart disease. In Maternal fetal medicine. Principles and practice. R.K. Creasy, R. Resnik, L. Bralow, editors. W.B. Saunders Co Philadelphia, Pennsylvania, USA. 233-242.

7. Carvalho, J.S., Mavrides, E., Shinebourne, E.A., Campbell, S., and Thilaganathan, B. 2002. Improving the effectiveness of routine prenatal screening for major congenital heart defects. Heart. 88:387-391.

8. Todros, T. 2000. Prenatal diagnosis and management of fetal cardiovascular malformations. Curr. Opin. Obstet. Gynecol. 12:105-109.

9. Moore, K.L., and Persaud, T.V.N. 1998. Before we are born: essentials of embryology and birth defects. W.B. Saunders Co. Philadelphia, Pennsylvania, USA. 259-300.

10. Bruneau, B.G. 2003. The developing heart and congenital heart defects: a make or break situation. Clin. Genet. 63:252-267.

11. Goldmuntz, E. 1999. Recent advances in understanding the genetic etiology of congenital heart disease. Curr. Opin. Pediatr. 11:437-448.

12. Srivastava, D. 2001. Genetic assembly of the heart: implications for congenital heart disease. Annu. Rev. Physiol. 63:451-469.

13. Stauffer, N.R., and Murphy, K. 2002. Prenatal diag nosis of congenital heart disease: the beginning. Crit. Care Nurs. O. 25:1-7

14. Levy, H.L., et al. 2001. Congenital heart disease in maternal phenylketonuria: report from the Maternal PKU Collaborative Study. Pediatr. Res. 49:636-642

15. NIH. 2000. Phenylketonuria: screening and management. Consensus statement developed at: Consensus Development Conference on Phenylketonuria (PKU): Screening and Management. October 16-18. Bethesda, Maryland, USA. http://consensus.nih.gov/cons/113/113_intro.htm.

16. Freedom, R.M., Leland, N.B., and Smallhorn, J.F. 1992. Neonatal heart disease. Springer-Verlag. London, United Kingdom. 7-17.

17. Berman, M.R. 2001. Parenthood lost: healing the pain after miscarriage, stillbirth, and infant death. Bergin \& Garvey Trade, Greenwood Publishing Group. Westport, Connecticut, USA. 224 pp.

18. Bennett, R.L. 1999. The practical guide to the genetic family history. Wiley-Liss Inc. New York, New York, USA. 251 pp.

19. Friedman, A.H., and Kopf, G. Advances in man agement of congenital heart disease: belping children lead healthier, happier lives. Yale-New Haven Children's Hospital booklet. New Haven, Connecticut, USA. 6 pp.

20. Copel, J.A., Tan, A.S.A., and Kleinman, C.S. 1997. Does a prenatal diagnosis of congenital heart disease alter short-term outcome? Ultrasound Obstet. Gynecol. 10:237-241.

21. DeVore, G.R. 1998. Influence of prenatal diagnosis on congenital heart defects. Ann. N. Y. Acad. Sci. 847:46-52.

22. Mahle, W.T., Clancy, R.R., McGaurn, S.P., Goin, J.F., and Clarke, B.J. 2001. Impact of prenatal diagnosis on survival and early neurologic morbidity in neonates with the hypoplastic left heart syndrome. Pediatrics. 107:1277-1282.

23. American College of Medical Genetics/American
Society of Human Genetics Test and Technology Transfer Committee Working Group. 2000. Tandem mass spectrometry in newborn screening. Genet. Med. 2:267-269.

24. US General Accounting Office. 2003. Newborn screening: characteristics of state programs. Washington, DC, USA. GAO-03-449, 2003. www.gao.gov/ new.items/d03449.pdf.

25. Hesselgrave, B.L. 2003. Helping to manage the high cost of rare diseases. Manag. Care Q. 11:1-6.

26. Brady, R.O. 2003. Enzyme replacement therapy: conception, chaos and culmination. Philos. Trans. $R$ Soc. Lond. B Biol. Sci. 358:915-919.

27. Bennett, R.L., et al. 2002. Fabry disease in genetic counseling practice: recommendations of the National Society of Genetic Counselors. J. Genet. Couns. 11:121-146.

28. American Society of Human Genetics Board of Directors, American College of Medical Genetics Board of Directors. 1995. Points to consider: ethical, legal and psychosocial implications of genetic testing in children and adolescents. Am. J. Hum Genet. 57:1233-1241.

29. National Society of Genetic Counselors. 1994. Position statement on prenatal and childhood testing for adult-onset disorders. Perspectives in Genetic Counseling. 17:5.

30. American Academy of Pediatrics, Committee on Genetics. 2000. Molecular genetic strategies in pediatric practice: a subject review (RE0023). Pedi atrics. 106:1494-1497.

31. Szudek, J., Birch, P., Riccardi, V.M., Evans, D.G., and Friedman, J.M. 2000. Association of clinical features in neurofibromatosis 1 (NF1). Genet. Epidemiol. 19:429-439.

32. 2002. Cystic Fibrosis Foundation Patient Registry, Annual Data Report, 2001. 2001. Cystic Fibrosis Foundation. Bethesda, Maryland, USA. www.cff.org/publications.

33. Charrow, J., et al. 2000. The Gaucher registry: demographics and disease characteristics of 1698 patients. Arch. Intern. Med. 160:2835-2843.

34. Small, G.W., et al. 1997. Diagnosis and treatment of Alzheimer disease and related disorders. Consensus statement of the American Association for Geriatric Psychiatry, the Alzheimer's Association, and the American Geriatrics Society. JAMA. 278:1363-1371.

35. Bird, T.D., et al. 1989. Phenotypic heterogeneity in familial Alzheimer's disease: a study of 24 kindreds Ann. Neurol. 25:12-25.

36. St. George-Hyslop, P.H. 2000. Molecular genetics of Alzheimer's disease. Biol. Psychiatry. 47:183-199.

37. 1995. Statement on use of apolipoprotein E testing for Alzheimer disease. American College of Medical Genetics/American Society of Human Genetics Working Group on ApoE and Alzheimer disease. JAMA. 274:1627-1629.

38. Roberts, J.S., et al. 2003. Reasons for seeking genetic susceptibility testing among first-degree relatives of people with Alzheimer disease. Alzheimer Dis. Assoc. Disord. 17:86-93.

39. Silverman, J.M., et al. 1994. Patterns of risk in firstdegree relatives of patients with Alzheimer's disease. Arch. Gen. Psychiatry. 51:577-586.

40. Hall, M.A. 2003. Genetic discrimination. North Carolina Genomics and Bioinformatics Consortium. Research Triangle Park, North Carolina, USA. Information sheet. 1-4.

41. Health Insurance Portablilty and Accountability Act, Public Law 104-191, US Statutes at Large 110 (1996).

42. Americans with Disabilities Act, US Code 42 (1994), 12101-12213.

43. Rocchi, A., Pellegrini, S., Siciliano, G., and Murri, L. 2003. Causative and susceptibility genes for Alzheimer's disease: a review. Brain Res. Bull. 61:1-24.

44. Nussbaum, R., and Ellis, C.E. 2003. Alzheimer's disease and Parkinson's disease. N. Engl. J. Med. 348:1356-1364.

45. OMIM: Online Mendelian Inheritance in Man. http://www.ncbi.nlm.nih.gov/Omim/. 